九州大学学術情報リポジトリ

Kyushu University Institutional Repository

FIELD STUDIES ON THE BIOLOGICAL CONTROL OF LEAFHOPPERS AND PLANTHOPPERS (HEMIPTERA : HOMOPTERA) INJURIOUS TO RICE PLANTS IN SOUTHEAST ASIA. AN ACCOUNT FOR THE YEAR 1979

Hirashima, Yoshihiro

https://doi.org/10.5109/2408

出版情報: ESAKIA. 16，pp.1-4，1981-03. Entomological Laboratory，Faculty of Agriculture， Kyushu University

バージョン:

権利関係 : 
ESAKIA， (16): 1-4. 1981

\title{
FIELD STUDIES ON THE BIOLOGICAL CONTROL OF LEAFHOPPERS AND PLANTHOPPERS (HEMIPTERA: HOMOPTERA) INJURIOUS TO RICE PLANTS IN SOUTH-EAST ASIA. AN ACCOUNT FOR THE YEAR 1979*
}

\author{
Yoshiniro Hirashima \\ Entomological Laboratory, Faculty of Agriculture \\ Kyushu University, Fukuoka 812, Japan
}

As the second year activities of the project entitled "Field studies on the biological control of leafhoppers and planthoppers (Hemiptera : Homoptera) injurious to rice plants in South-East Asia", field works were carried out in the Philippines and Taiwan in 1979, as follows:

In the Philippines, the Bureau of Agricultural Extension, Quezon City (Dr. Francisco R. Fentutar, Director; Mr. P. W. Resma, Entomologist) and the Department of Entomology, College of Agriculture, University of the Philippines at Los Baños (Dr. Bernardo P. Gabriel, Chairman; Dr. Clare R. Baltazar, Professor of Entomology; Mr. Leodegario E. Padua, Insect Pathologist) were main institutions by which our field activities were supported. Our team (K. Aizawa, Kyushu Univ., K. Yano, Yamaguchi Univ., and K. Morimoto, Kyushu Univ.) arrived at Manila on July 24, then a 50-day activity was taken place. Field works were done in Luzon and Mindanao (for places visited see Fig. 1), supported further by many institutions and scientists such as the Bureau of Agricultural Extension, Davao City (Mr. J. Y. Solomon, Regional Director; Mr. Honorio V. Lumain, Entomologist), Bureau of Agricultural Extension, La Trinidad, Benguet (Mr. Jose de la Cruz and Mr. Avelino Pistyla), Bureau of Agricultural Extension, Banaue, Ifugao (Mr. Emilio H. Abayao) and Forest Research, Paper Industries Corporation of the Philippines, Bislig (Dr. Ireneo L. Domingo, Director; Mr. Mamerto L. Garcia). As a result, a great many insects as well as biological informations were gathered from paddy fields. As a matter of course, these include natural enemies of rice leaf- and planthoppers such as the predacious bugs, pipunculid flies, etc.

In addition, entomological observations and collectings were done at many localities, for example, at Banaue, La Trinidad, Mt. Santo Tomas (Baguio), Mt. Makiling (Los Baños), Quezon National Park, and Bislig, and many interesting insect specimens were collected. On August 20, our team visited the Tiaong Experiment Station, Quezon, which belongs to the Bureau of Plant Industry. Here, the biological control of the coconut black

\footnotetext{
* Supported by the Grant-in-Aid for Overseas Scientific Survey, No. 504337, Ministry of Education, Science and Culture.

Special report from the Entomological Laboratory, Faculty of Agriculture, Kyushu University, Fukuoka.
} 


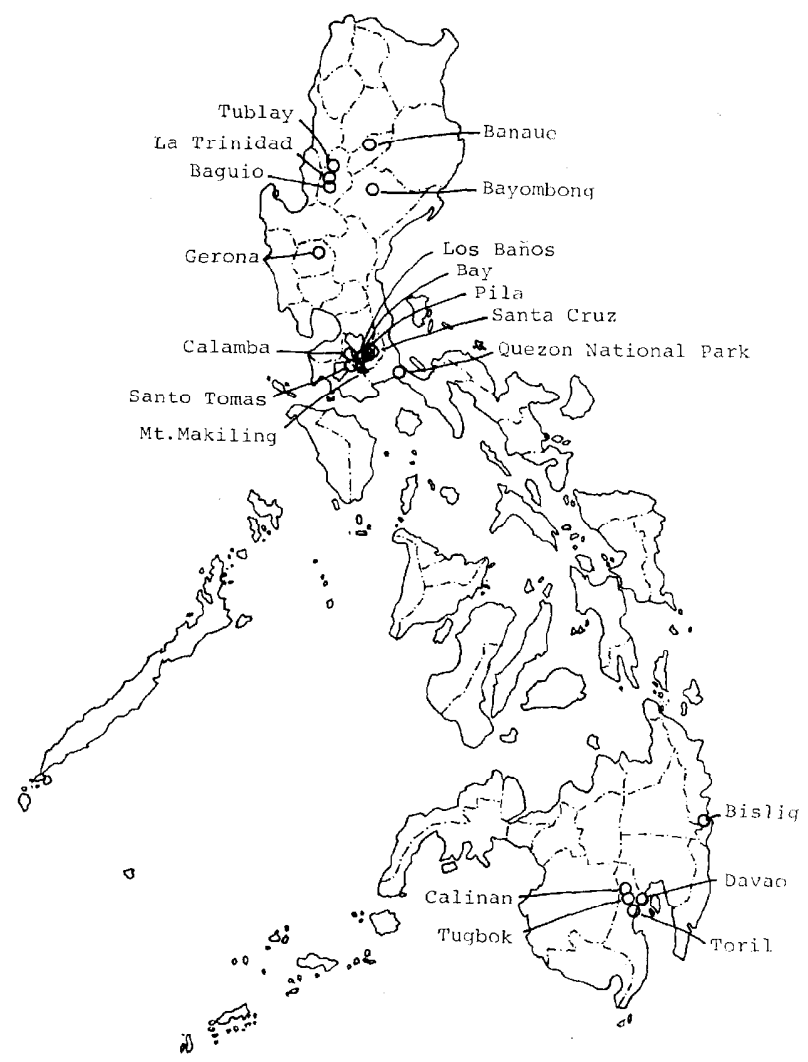

Fig. 1. Map of the Philippines with location of the places visited.

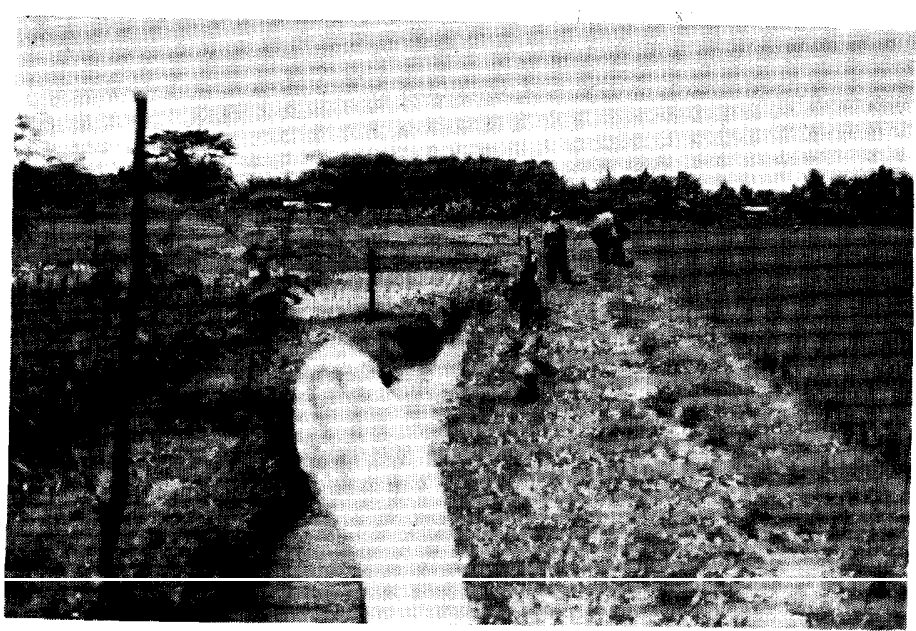

Fig. 2. Irrigated paddy fields at Toril, Davao City. Various stages of the crop a seen (Photo: K. Yano) 
beetle, Oryctes rhinoceros, by the green muscardine fungus, Metarrhizium anisopliae, was discussed.

In Taiwan, a 50-day survey was commenced from August 8 when our team (T. Miura, Shimane Univ., M. T. Chûjô, Kyushu Univ. and myself) arrived at Taipei. Accompanied by Dr. Yau-i Chu, Professor of Entomology, Department of Entomology and Plant Pathology, National Taiwan University, Taipei, who is also an investigator of the project, field works were made at almost all principal rice production areas in Taiwan (Fig. 3; also confer Miura et al., 1981, Esakia, (16) : 39). The following institutions and scientists supported our field works: Plant Protection Center, Taichung (Dr. Gwo-then Li, Director), Taiwan Agricultural Research Institute (Mrs. Shui-then Chiu, Head of Department of Applied Zoology), Taichung District Agricultural Improvement Station, Taichung (Mr. Kuangchi Su, Director; Mr. Ching-chung Chen, Entomologist), Chiai Agricultural Experiment Station, Chiai (Mr. Ching Huan Cheng, Entomologist and Chief of Division of Plant Protection), Taiwan Sugar Research Institute, Taiwan (Dr. Yung-song Pan, Head of Department of Plant Protection), Mr. Yi-hsiung Tseng (Section Chief, Tainan Branch Office, Bureau of Commodity Inspection \& Quarantine, Taiwan), Tainan District Agricultural Improvement Station, Tainan (Mr. Fu-cheng Yen, Entomologist), Kaohsiung District Agricultural Improvement Station, Pingtung (Mr. Hsin-chuan Lee, Entomologist), Taitung Dis-

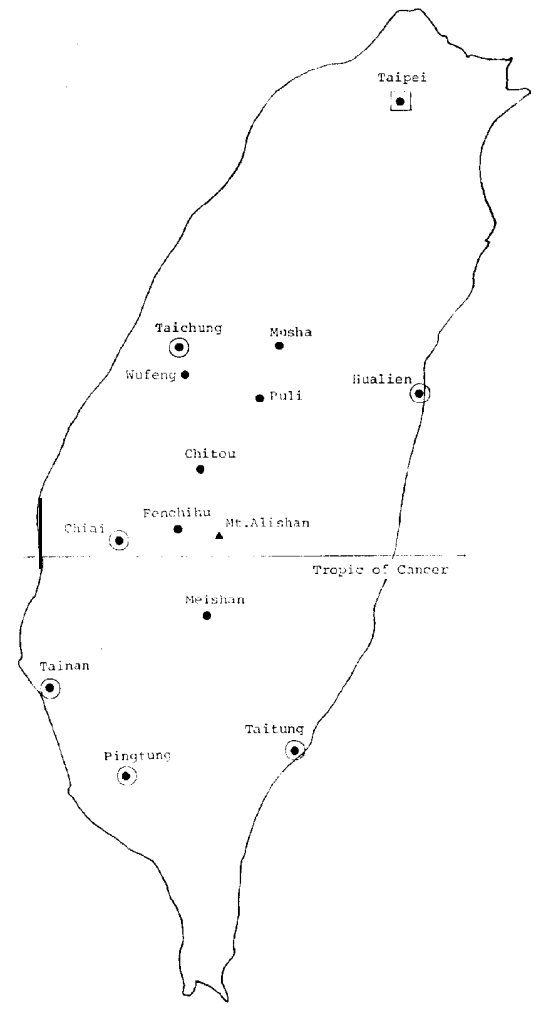

Fig. 3. Map of Taiwan showing main places visited. 
trict Agricultural Improvement Station, Taitung (Mr. Teng-shui Wu and Mr. Ching-ho Liu) and Hualien District Agricultural Jmprovement Station, Hualien (Mr. Tsai-wang Tsai, Director). Thus, field investigations were carried out throughout Taiwan with no problem. Many biological informations as well as insect specimens from paddy fields were collected. Egg and nymphal parasites of rice hoppers and predacious insects of the latter including ants were especially carefully collected.

Tn addition, extensive entomological observations and collectings were done at many places such as Musha (ca. 1, $100 \mathrm{~m})$, Puli, Chitou, Kuantzuling, Fenchihu (1,405 m), Alishan $(2,274 \mathrm{~m})$, Meishan $(864 \mathrm{~m})$. Chiaisien, etc. On September 7, our team visited the Hsingying Sugarcane Experiment Station at Liu-ying Hsiang, which is one of the substations belonging to the Taiwan Sugar Research Institute. The Hsingying Station is specialized in the mass-production of Trichogramma australicum for control of one of the sugarcane borers Argyroploce (Eucosma) schistaceana. The biological control program here has been successfully conducted when it was re-opened on a large scale at 3 sub-stations in 1970. They use the eggs of the rice moth, Corcyracephalonica for rearing Trichogramma australicum. The technique and the extent of program were impressive. On September 13, we visited the Asian Vegetable Research and Development Center (AVRDC) at Tainan. There we met with Dr. N. S. Talekar, Associate Entomologist and specialist in the control of soybean insects. His research work at this station is also interesting.

Thus, our field works in the Philippines and Taiwan were very productive. We are grateful to the authorities of the institutions and scientists we contacted for their helpful assistance and cooperation.

The progress report and many papers concerning the results of our study are in preparation. Some of these are published in this issue of Esakia No. 16. For the first year activity confer Hirashima et al., 1979 (Esakia, No. 13, pp. $1-20,1$ pl.). 